\title{
Four-frame gated optical imager with 120-ps resolution
}

\author{
P. E. Young. J. D. Hares, J. D. Kilkenuy, \\ D. IT. Plilliun, E. M. Camplselt \\ Lumrence Livermore Nutional Lahoratory, P. O. Box 808. Lincrunom, CA 94550 \\ Abstract \\ UCRL- 98419 \\ DEB8 011735
}

In this papex we rlescribe tlec operation and applientions of a framing camern capable

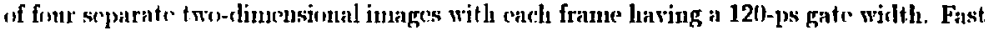

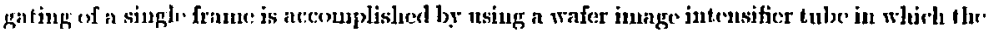

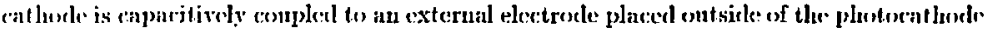
uf the tule. This chetrode is then pulsed relitive to the microchanuel plate by a uarrow (120 ps), higli-voltage pulse. Multiple framess are olstained by usiug multiple gated tulus

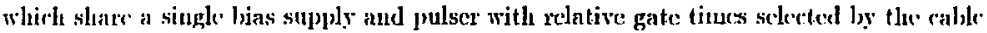

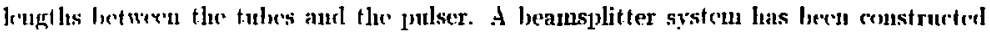

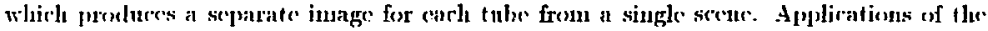

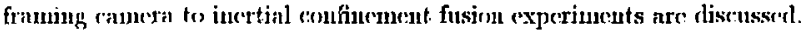

P.ACS mml,3ers: 07.68, 52.î.K, 52.25.R, 52.50.J 


\section{INTRODUCTION}

The eriterion for the time resolution of a framing amean is given by the requimel

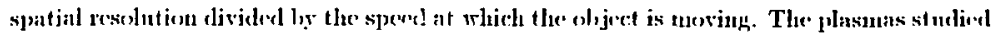

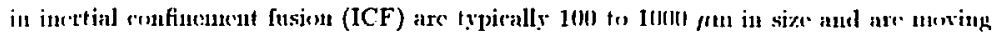

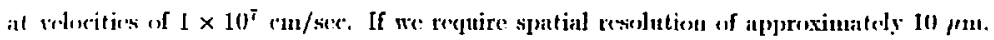
this inplies frame times an the order of 100 picoseconds. Prescut laser pulses of interest

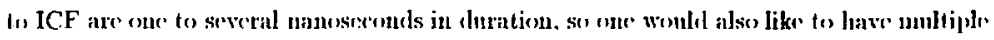
[manes to study the crolution of the plasma. The time delay betwern frames shomld bu asy to moljust.

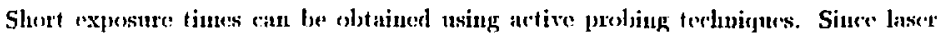

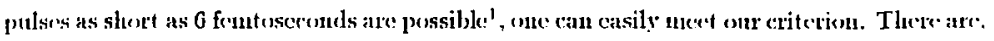

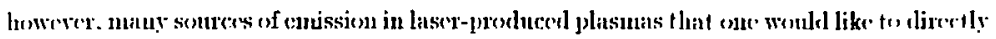

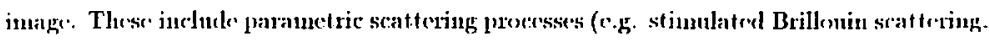

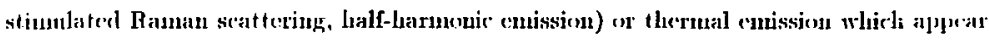

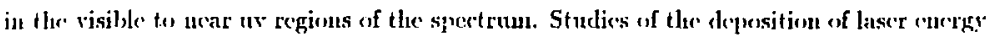

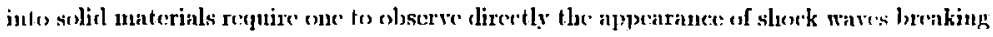

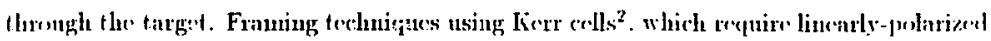

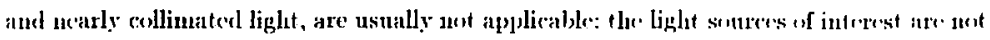

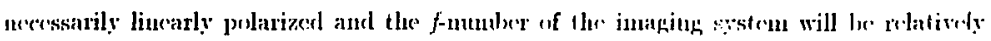

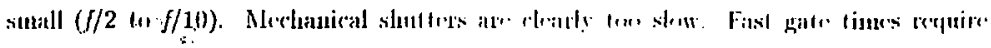

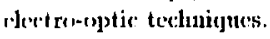




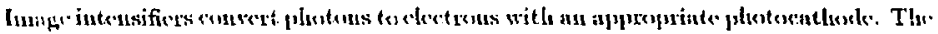

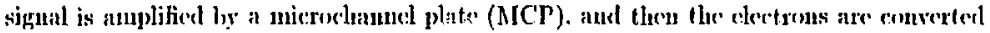

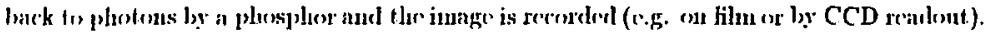

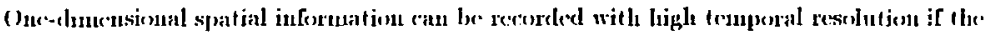

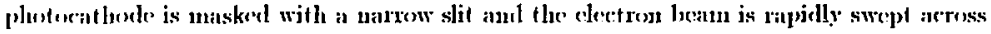

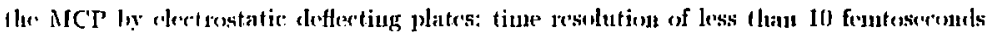

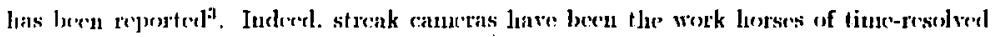

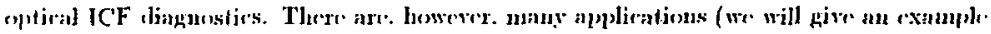

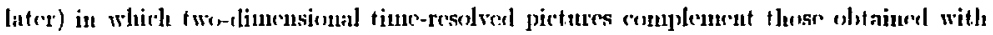

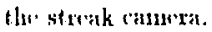

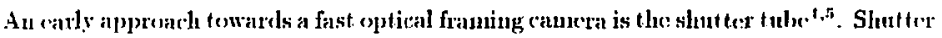

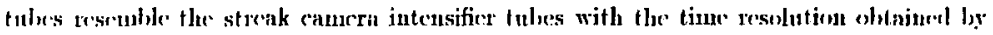

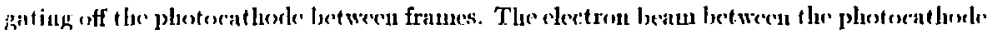
and the $\mathrm{MCl}$ is alcflected betwere frames to a new spatial region of the MCP in orrler to whinil multiple francs. This precedure requires that a complex. time-rlependent rentage

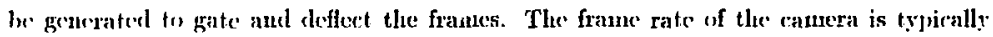
linitred to foo ps by the transit tiue of the electem beam thromgh the deflection plates.

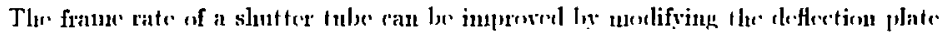

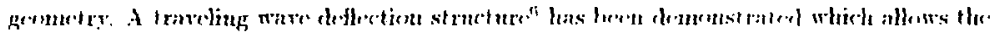

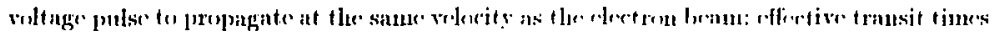

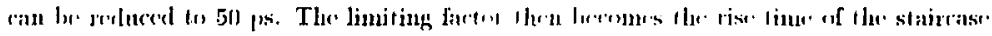

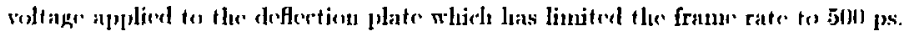




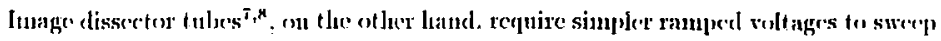

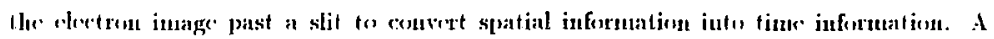

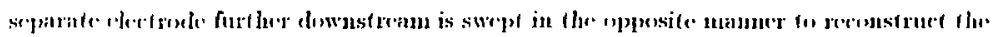

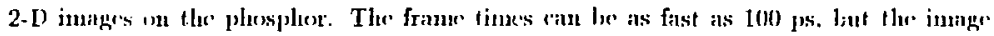

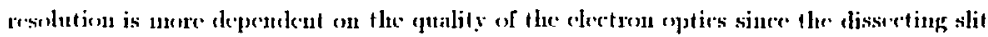

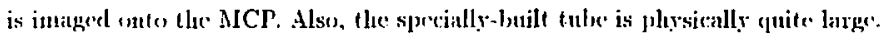

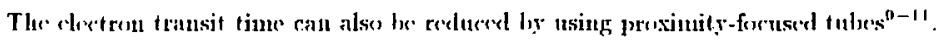

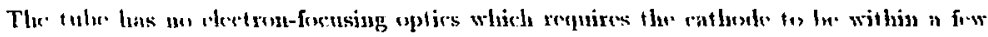
nillineters of the phosplenr. Fast frimes can loc obtained by applying a sleort chertrimal

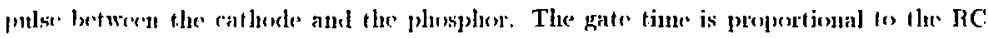

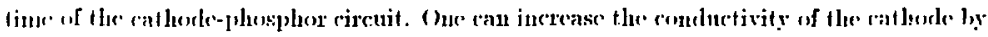

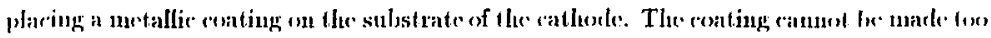
thirk withemt compromising the transmission of the tube. This limits the enedurtivity of

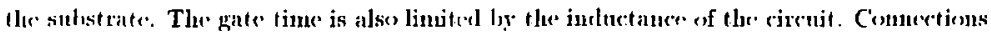

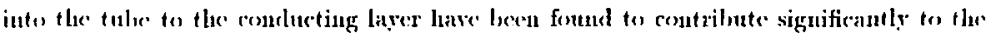
total incluctance of the ganling circuit and gate times hare lowe limited to 200 ps.

In the remainter of thes paper ne rliscuss the gaterl eptienal imager (GOI) that we

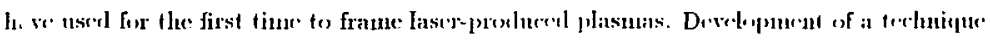

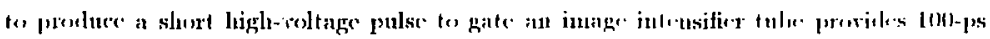

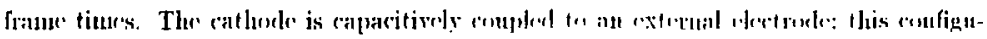

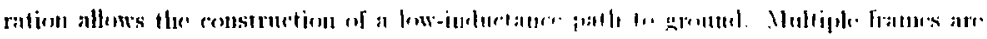

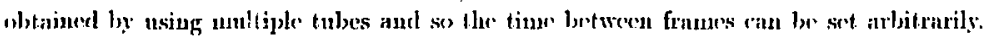


The intage intensifice tules are rendily antalable, reliable, and rery compact. An "xamplle of an application of this candera at this labenatery is presenterl in the thirel section.

\section{DESCRIPTION OF THE GATED OPTICAL IMAGER}

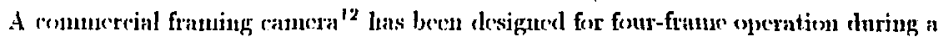
single crent. Eath chandel of the Gol uses a wafer intensifier tule ${ }^{13}$ which has an S20

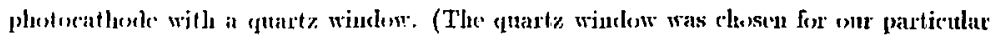

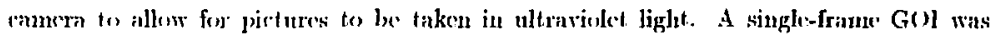

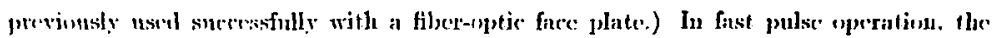

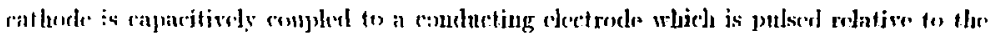

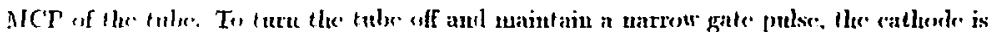

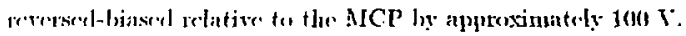

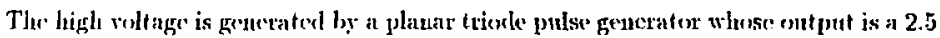
kF prolse with a risetine of less than 1.5 ns. The pulse is then shortened to npproximately

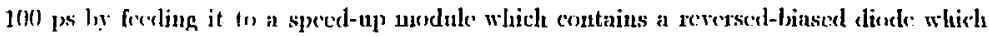

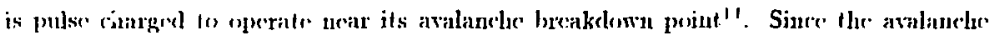

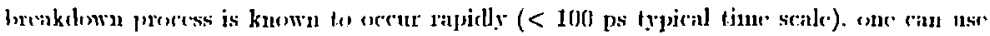

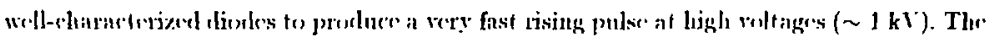

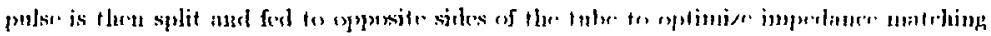

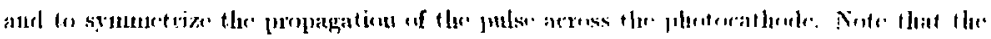

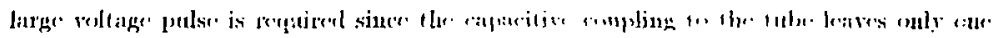

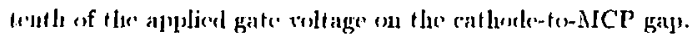




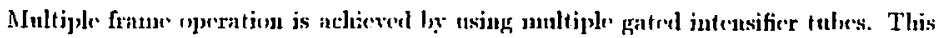
reviures that the optical system provirle a separate image to cach Gol channel. hut this

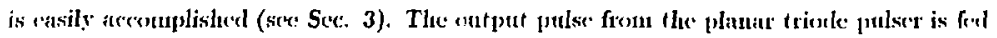

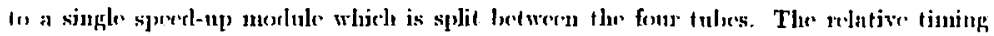

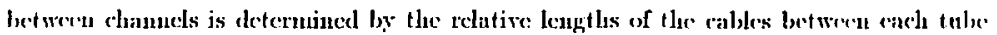
and the spered-ny module. This arrangenent is illust mated in Fig. 2.

The wirlth of the gate pulse has been verified optically using a strobe techelenier with

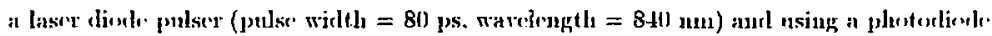
16 measure the light cuitted at the pluspher (P201). at is se'n in Fig. 3. This is a plet of interrated light untput versols relative delay berweren the gate and the lased and was

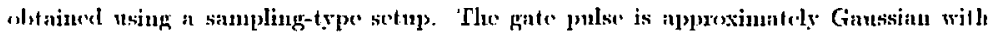

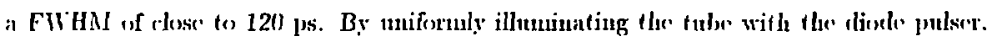

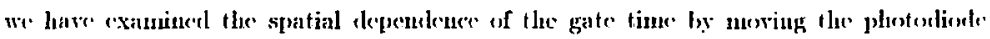
meciver acruss the phesphure; the variation is less than $20 \mathrm{ps}$. The gate tine is teteruiurd

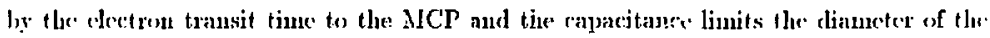

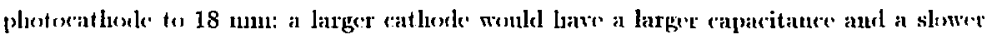
Linte time.

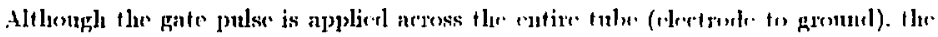

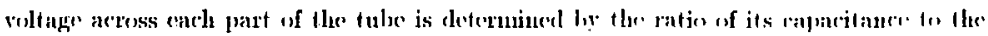

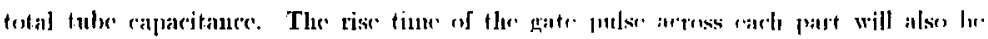

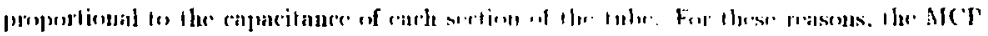

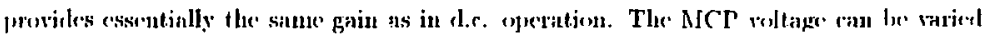




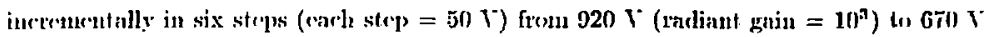

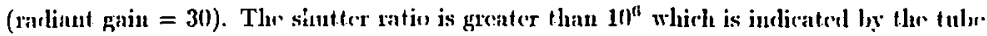

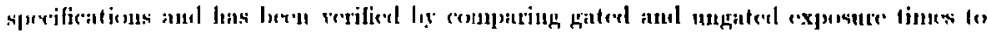

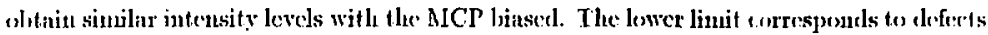
in the MC'P.

The spatial resulution of the gated tube lans bern investigated. A contrast tanusfer

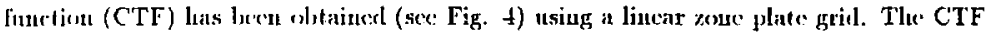

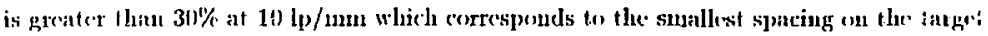

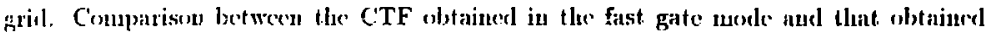

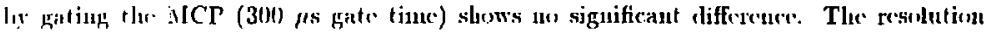

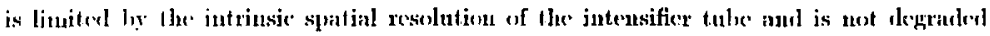
ly the exsemal clectroctes. Nole that the monsured CTF inchules offerts of recerting the image onto filn: tle finite thickuess of the cmutsion degrades the system mespontse at higher sputial frecplunciest.

\section{APPLICATIONS}

The fentr frume Gol is gresently a routine eljagnestic uscel in conjunction mith the

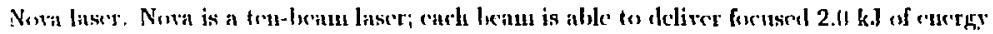

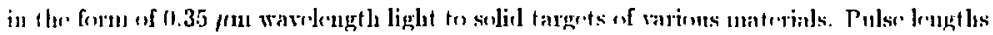

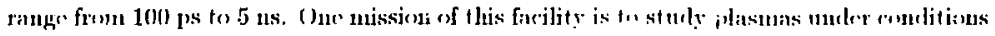

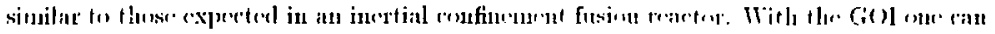

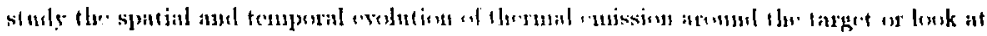

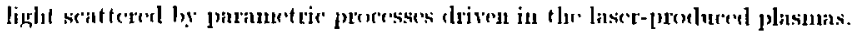




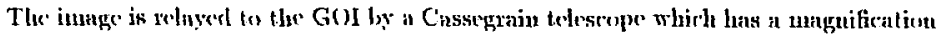
of 8.45 and lans an input f-nmulere of 10 (the tedescope is 2 moters from the target): this

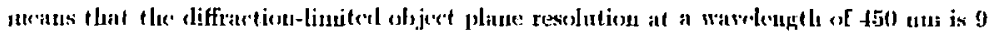

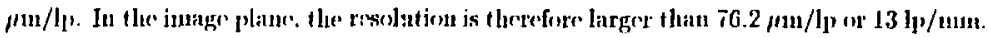
This is romparable to the image reselution of the tulw. Fone images of the target of ueaty

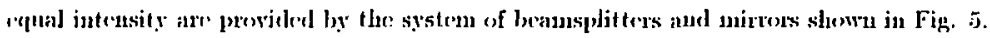

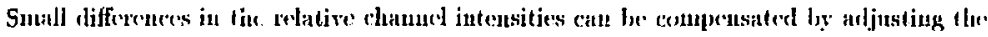
ACP gain of cath tulne indivirlually.

An rxample of the use of the GOt is illustrated in Fig. 8. In this experiment, two

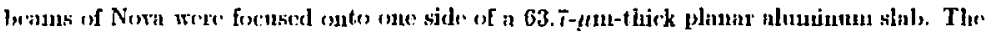

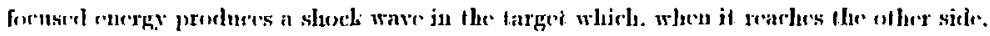

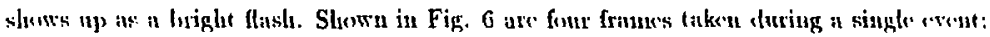

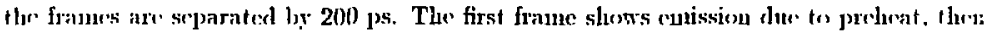

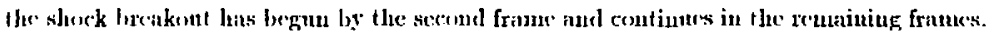

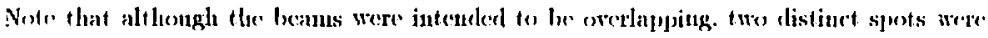

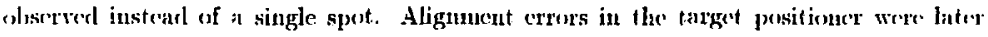

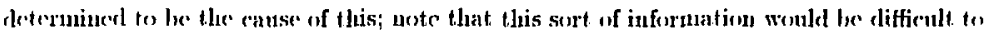
bibtain using a streak canera alone without fort nitions alignment.

\section{SUMMARY}

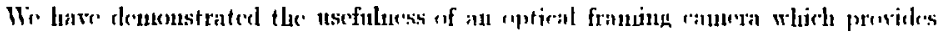

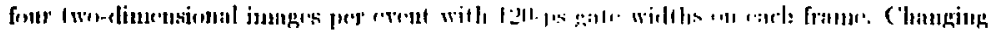

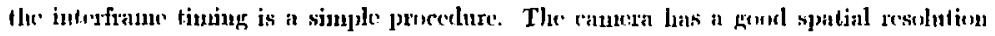




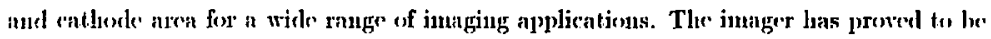
a useful and reliable diagnesstic on the Nowa laser system.

Thes work was performerl umer the anspices of the U. S. Department of Encrgr ly

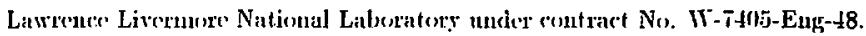




\section{REFERENCES}

1. R. L. Fork, C. 11. Brito C1uz, P. C. Berker. C. Y. Slmuk, (1)t. Lett. 12, 183 (108i).

2. M. C. Richardsun and K. Sala, Appl. Physs. Lott. 23. 424 (19i3).

3. İ. Kinushita. M. Ito. Y. Sızuki. Row. Sri. Instrum. 58. 932 (1087).

4. E. K. Zavojsky and S. D. Franchenko, Appl. (1pt. 4, 1155 (1065).

5. For cxample the Intacon tulue (mamafactured by Englishl Electric Valre, Lti., Eng-

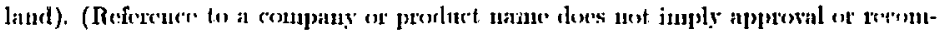

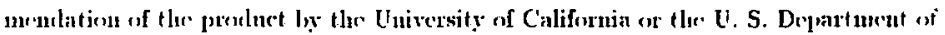
Emergy to the cxolusion of others that miỵ be suitalsh.)

6. N. Fizm. T. A. Hall. E. MrGoltlick. Apụl. Phỵs. Lett. 46. i31 (1085).

†. R. Kidlil,jian aud S. W. Thunas. Rev. Sti. Lnstrum. 54, 1620 (1983); R. Kalil,jian. Rru. Sri. Instrum. 49, 891 (1078).

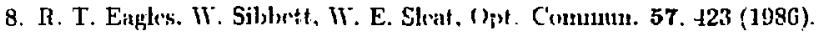

9. A. S. Liurly, A. E. Iverson, Prọ. SPIE 348, 178 (1982).

10. IV. Pfoiffor, D. Wittuter, Proc: SI'1E, 491, 254 (1084).

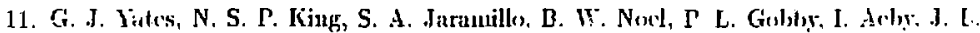
Ditch, IEEE Truus. Nucl. Sci. NS-31. 48t (1981).

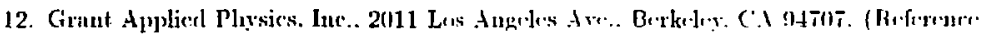

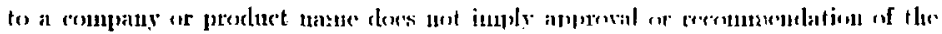

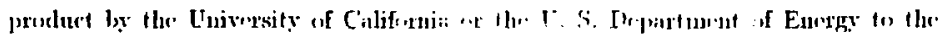
txrlusiou of others that nay be suitabie.) 
13. H. K. Pollelen. in Applied Opties and Optiral Enqinerriny. Val. V1, colited ly P.

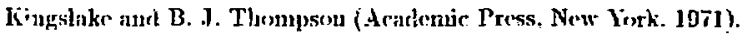

14. I. V. Curkhos. A. F. Karrlesysurv, S. I. Shemberci. lnstrum. Exp. Terh. 24, 06i (1081) [Pril. Tekl. Eksip. 4, 135 (1981)]. 


\section{FIGURE CAPTIONS}

1. a) A rien af the rour of the faniug caunera sluming the plysical connections with

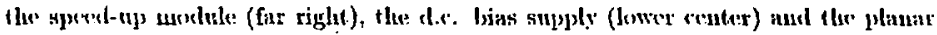

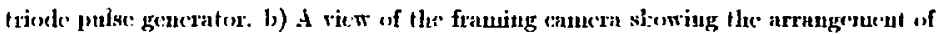
the frmr gatol intusifior tnles.

2. Diagran illustrating the contuections used for four-frame speration of the ranum.

3. Mesusurerl gate width of the camen't

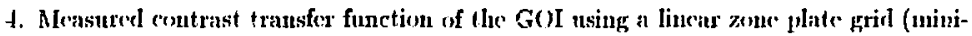
munu spincing $=101 \mathrm{l} / \mathrm{umu})$.

5. Srhemo for providing juages of nearly equal intensity and ai the same time to all four G(I) drantuis.

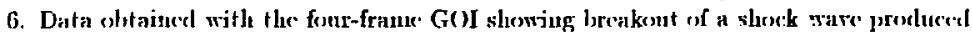
in H1 alnuminnu shlsh tanget. 


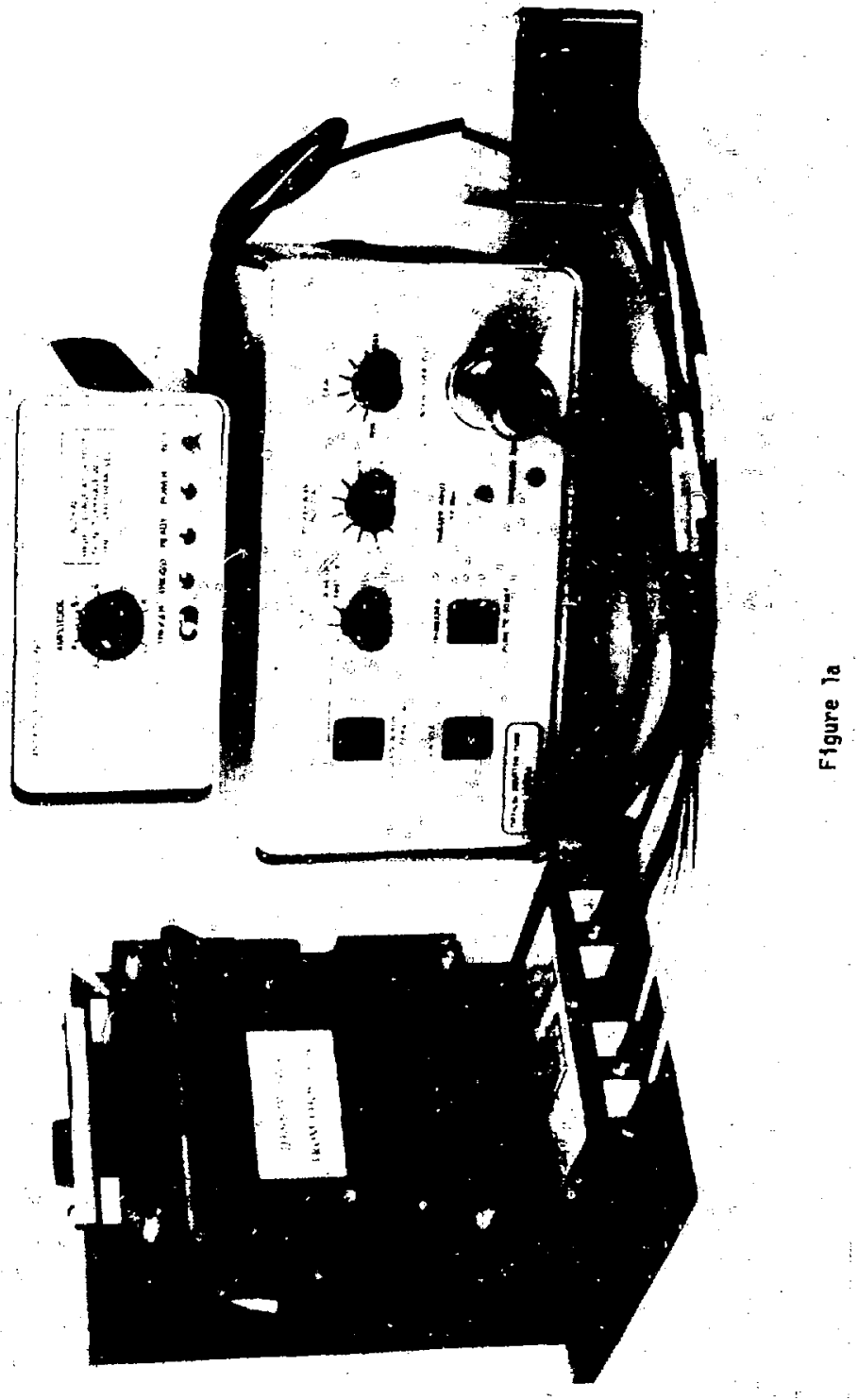




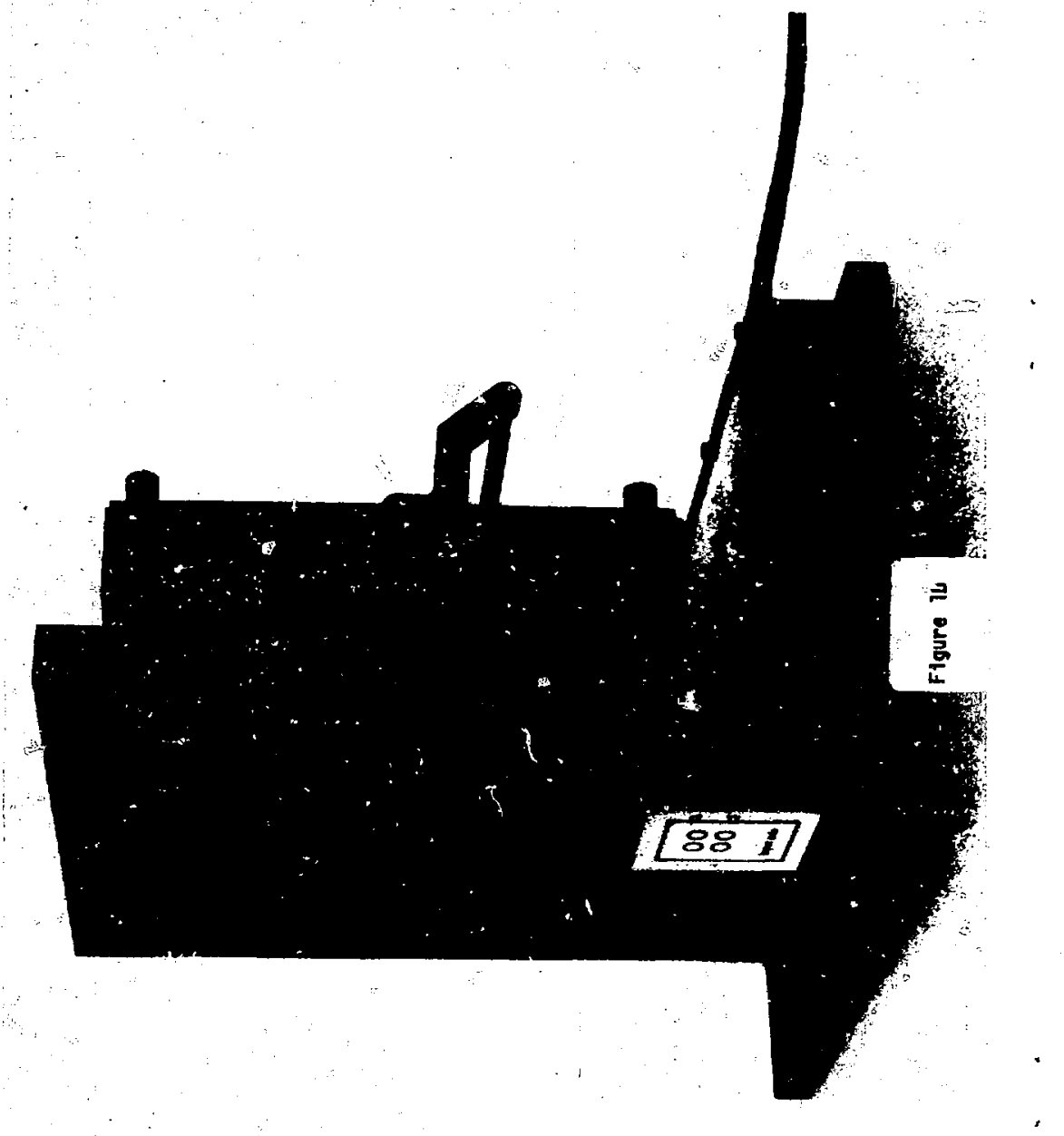




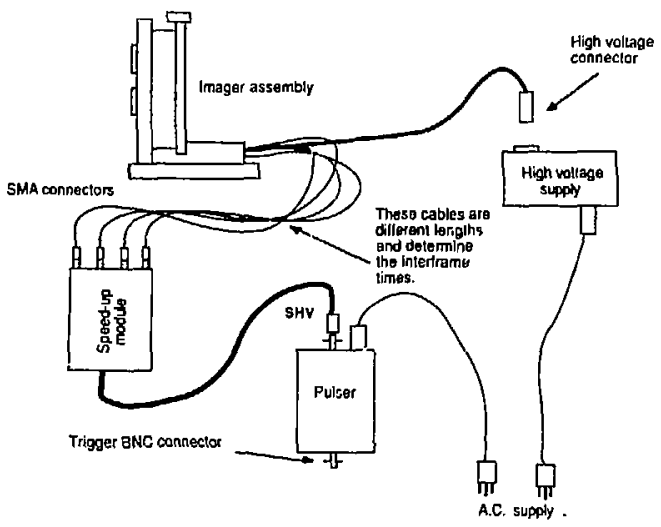

Figure 2 

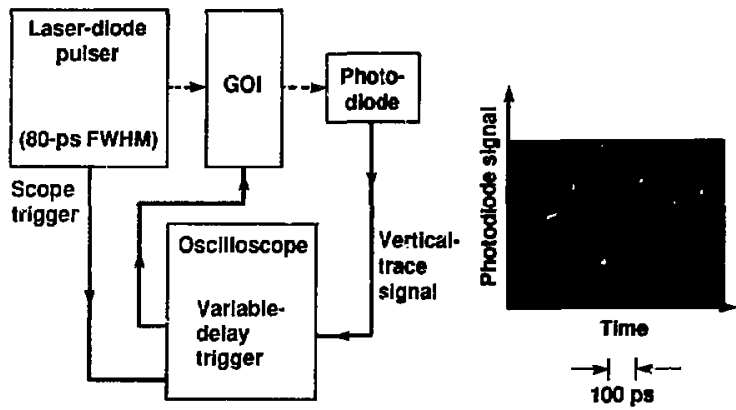

Figure 3 


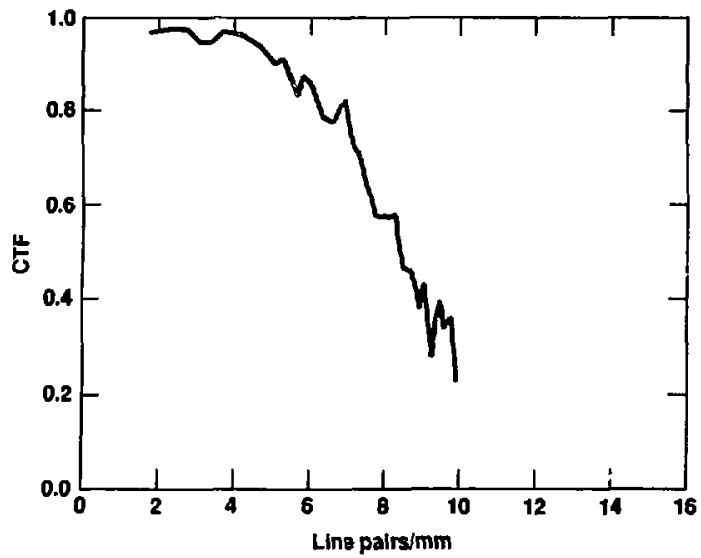

Figure 4 


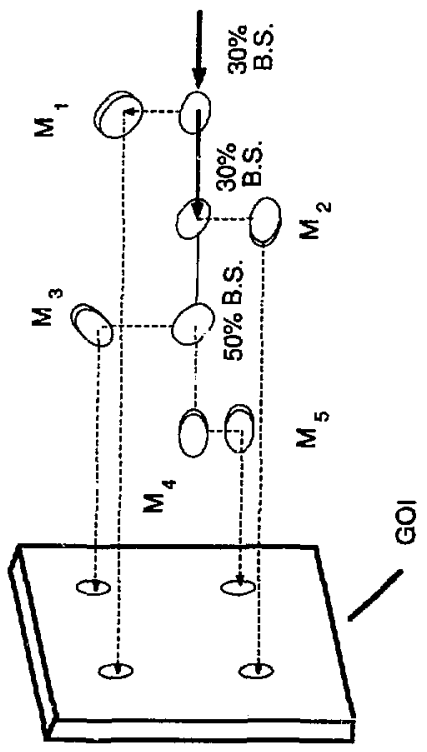

高

$s$ 


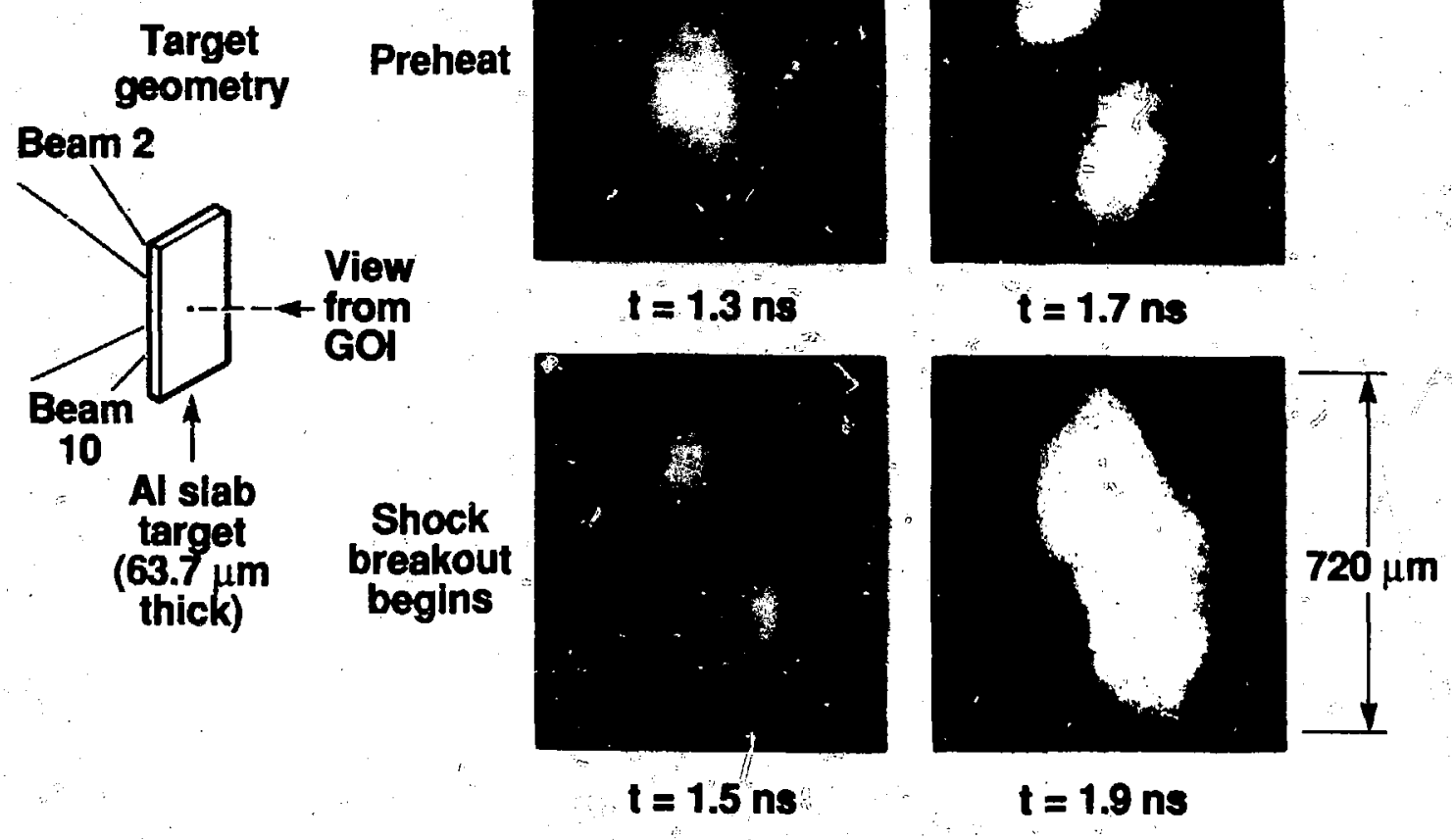

Figure 6 